\title{
Perihilar Bile Duct Cancer TNM Finding v7
}

National Cancer Institute

\section{Source}

National Cancer Institute. Perihilar Bile Duct Cancer TNM Finding v7. NCI Thesaurus. Code $C 90220$.

A finding about one or more characteristics of perihilar bile duct cancer, following the rules of the TNM AJCC V7 classification system. Sarcomas and carcinoid tumors are not included. (from AJCC 7th Ed.) 